\title{
Assessment of road traffic performance of the Tsunami evacuation road in Padang Municipality area based on the traffic volume simulation approach
}

\author{
Yossyafra Yossyafra ${ }^{1 *}$, Nurhuda Fitri $^{1}$, Rahmat Punama Sidhi ${ }^{1}$, Yosritzal Yosritzal $^{1}$, Deni Irda Mazni ${ }^{2}$ \\ ${ }^{1}$ Civil Engineering Department, Faculty of Engineering, Universitas Andalas, Indonesia. \\ ${ }^{3}$ Civil Engineering Study Program, Universitas Dharma Andalas, Indonesia.
}

\begin{abstract}
There are many cities on the west coast of the Sumatra, which are at high risk of the Tsunami disaster. Regional Regulations on Regional Spatial Planning for each City/ Regency have compiled disaster mitigation by constructing several evacuation roads. This study wants to illustrate: what are the volume of traffic generation and road performance, if there is a Tsunami disaster. The simulation is developed by predicting traffic volume based on parameters, population density, vehicle ownership, land use, and activities in the area around the road. The assessment was carried out on two tsunami evacuation roads in the city of Padang, West Sumatra Province. The results show that the highest traffic volume occurred in the period from 06.30 a.m until 3:00 p.m., during school activities. One of the roads will not be able to accommodate the volume of traffic during a disaster, due to significant traffic congestion. This study shows that: (1) the period of activity and land use are two main parameters, which must be considered in designing tsunami evacuation roads, (2) The degree of saturation ratio and the ratio between the capacity of sections of Tsunami evacuation routes can be proposed as a parameter for assessing the performance of Tsunami evacuation roads in urban areas.
\end{abstract}

\section{Introduction}

Law of the Republic of Indonesia number 24 of 2007, concerning Disaster Management, prioritizes handling based on the safety of human life [1]. One option in reducing the loss of lives from the impact of disasters is to increase preparedness with the availability of evacuation routes, which can facilitate the evacuation of people to safe places in the event of a disaster. Strategies in tsunami preparedness from various city governments in Indonesia focused on the following: developing an early warning system, planning an evacuation route, conducting evacuation drills, and raising local awareness [2].

Will a road designated as an evacuation route (horizontal evacuation route or street to a building on a vertical evacuation) in a city be able to accommodate the volume of traffic that will pass through, and meet the standard criteria for evacuation routes? For this reason, an assessment of the evacuation road is required. One method that can be done is to simulate traffic volume prediction on the tsunami evacuation road section. Simulations can be done by considering the demand for evacuation movements that will occur on these roads. Various traffic flow scenarios that might occur due to land use and activity time in the catchment area (service area coverage) of the evacuation road are modeled.

\section{Literature Review}

\subsection{Tsunami Evacuation Route}

Evacuation routes are roads or paths that are designed to be passed by people and vehicles when evacuating during a disaster [3]. Evacuation routes are very important for a city where there is a high-risk area for tsunami disasters. Evacuation routes can be either horizontal and / or vertical evacuation routes. Indonesian Standard [3] technically requires that tsunami evacuation routes should be: (a) planned with the existence of primary and additional lanes in tsunami-prone areas, (b) should not cross rivers or bridges, especially those near the coast, (c) several evacuation routes made parallel to away from the coastline, prioritizing open coastal areas, without cover trees (palm trees, coastal fir, mangroves), (d) in densely populated areas, designed block evacuation systems, which are limited by roads or streams, to avoid congestion, (e) at very low elevations, a temporary safe area system is created, in the form of buildings or artificial hills as temporary safe places, or providing a green line to protect tsunami-prone areas, (f) Evacuation signs are needed to guide it to a safe gathering place [4], (g) Arranging the direction of traffic along the main tsunami evacuation route, which is arranged according to the direction of the evacuation.

\footnotetext{
* Corresponding author: yossyafra@eng.unand.ac.id
} 
Dewi [5] has developed a method for selecting effective evacuation routes using a Geographic Information System (GIS) device, network analysis, and various GIS techniques used to determine the location and potential capacity of a suitable evacuation building (ESB). Evacuation plays an important step in saving human lives.

Some researchers ([3], [6], [7], [8], [9], [10]) have researched tsunami evacuation roads, both on how to determine and choose evacuation routes in a city. However, of all the articles and books that have written about the tsunami evacuation route, there is no clear and complete written mentioning what parameters are calculated or used in designing tsunami evacuation routes and how to assess or evaluate the performance of tsunami evacuation routes that have been built in many cities

\subsection{Indonesian Road Capacity Standards and Road Section Performance}

Road capacity is the maximum traffic flow through a point on the road per unit hour under certain conditions [11]. Capacity is calculated based on the value of Basic Capacity (pcu/hour), and road width adjustment factor, direction separator adjustment factor (only for undivided roads), shoulder barriers adjustment factor, and city size adjustment factor.

The performance of a road is a quantitative measurement that describes certain conditions that occur on the road. The performance of a road is influenced by several factors such as road capacity, degree of saturation, speed, etc. The performance of a road is determined by the Degree of Saturation (DS) parameter, which is the ratio of the maximum traffic volume (current) value (pcu/hour) to capacity (pcu/hour). The road performance index shows the condition of the performance of the road in serving the flow of traffic that passes through the road. An illustration of whether a road segment has a problem or not, based on the assumption that if a road segment gets closer to its capacity, the ease of moving becomes more limited [9].

\section{Methodology}

The methodologies adopted for this research arose from the research objectives. The research followed the typical sequence of stages, such as; identification, investigation, development, application, and summarisation. This study, the process begins with identifying local regulations on evacuation routes, in the municipalities and regencies on the west coast of West Sumatra Province. The next stage is to identify the existing land use in the catchment area of the tsunami evacuation route. Demographic data, such as the number and density of population in the catchment area, as well as the economy and vehicle ownership, are essential data. Then, several assumptions are made as an illustration or simulation of peak hour conditions when a tsunami disaster occurs. Assumptions are influenced by several factors, including the catchment area, which is predicted to pass through the evacuation route during the tsunami, the number of population, motorized vehicle ownership, the age distribution of the population, and the number of family heads who live in the catchment area.

Several problem constraints are needed in this study, including (a) The research was conducted on a road section that was used as a tsunami evacuation route. (b) Primary data were taken using the on-site survey method by direct checking, and primary data collection is carried out on working day conditions (busy days). (c) Prediction of experts in the field of Geophysics is used, i.e., they predict tsunami waves, which can strike in 5-15 minutes. (d) The direction of traffic flow under disaster conditions is assumed to be one direction.

\section{Results and Discussion}

\subsection{Road Type and Capacity}

The Municipality of Padang is the capital of the Province of West Sumatra, which is located on the west coast of the island of Sumatra, directly facing the Indonesian Ocean. The area lies in $00^{\circ} 44^{\prime}$ and $01^{\circ} 08^{\prime}$ South Latitude and $100^{\circ} 05^{\prime}$ and $100^{\circ} 34^{\prime}$ East Longitude. Located at an altitude between $0-1853 \mathrm{~m}$ above sea level. The geographical position is close to the collision of two active Indo-Eurasian plates. Movement between plates can trigger earthquakes that could potentially be followed by a tsunami.

If a review of the population affected by the tsunami disaster becomes a risk parameter, the Municipality of Padang is the highest-risk urban area in the world from the Tsunami disaster. Padang has the largest population in the province of West Sumatra, which is 927,168 people [12], most of whom live in coastal areas.

Based on historical records, Padang was hit by two Tsunami disasters, in 1604 and 1833. The 2004 Aceh Tsunami, and the 2009 Padang earthquake, have given valuable lessons to the people of Padang. So that the Padang Government, through the Municipal Regulation, number 4 of 2012 concerning the Regional Spatial Plan (RTRW), in which the area is designated as six roads. Sector-IV (Fig. 1) was chosen for the assessment because the population in this sector is the largest in number and very high risk compared to other sectors.

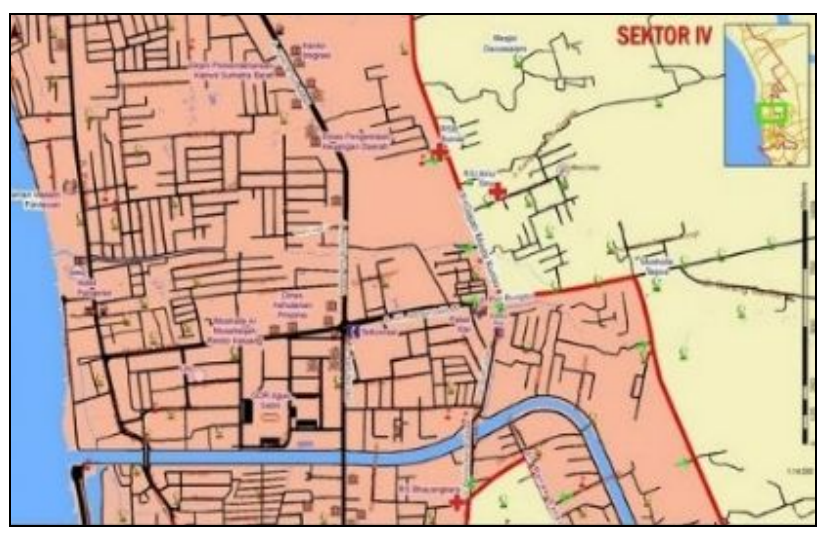

Fig. 1. Sector-IV Padang Tsunami evacuation corridor 


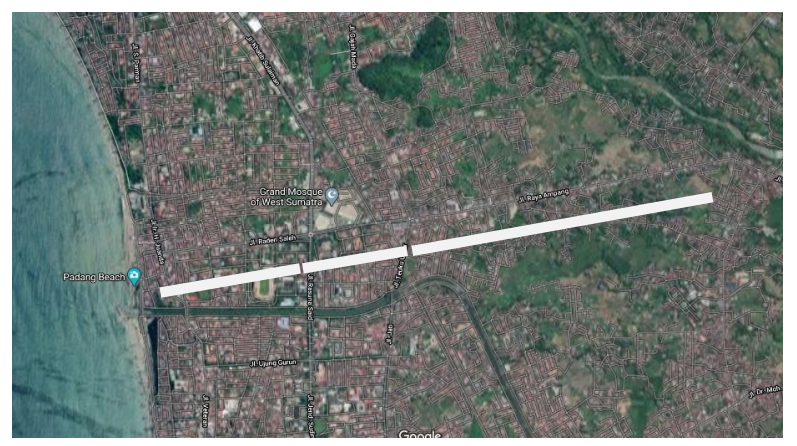

Fig. 2. Roads in Sector-IV, designated as Tsunami evacuation roads

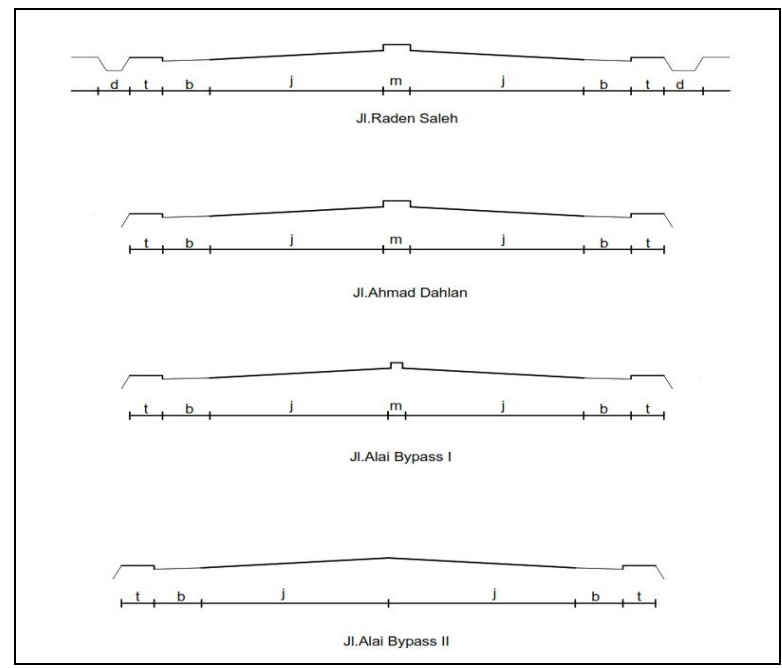

Fig. 3. Cross-section of Tsunami evacuation roads

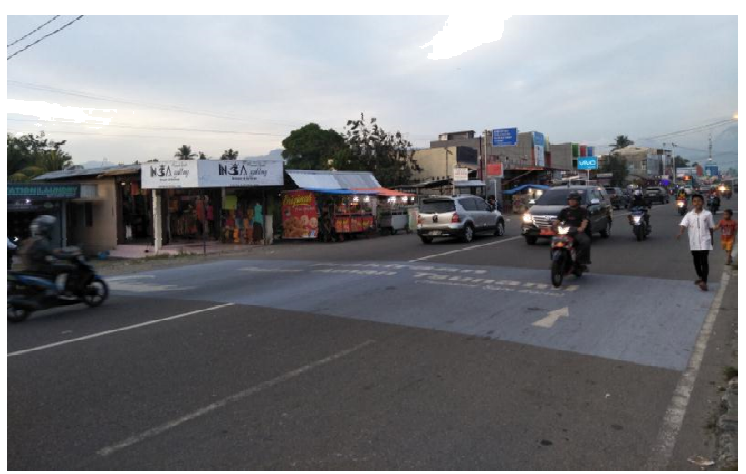

Fig. 4. Tsunami safe zone road markings on Alai - By-pass roads

Table 1. Typical of the three roads.

\begin{tabular}{|l|l|l|}
\hline Item & $\begin{array}{l}\text { Raden Saleh, and } \\
\text { Ahmad Dahlan }\end{array}$ & Alai-by Pass \\
\hline Type & $4 / 2 \mathrm{D}$ & $4 / 2 \mathrm{UD}$ \\
\hline Road Width & $2 \times 6,60 \mathrm{~m}$ & $14,00 \mathrm{~m}$ \\
\hline Shoulder & $2 \times 1,50 \mathrm{~m}$ & $2 \times 1,00$ \\
\hline Drainage & $\begin{array}{l}\text { Open channel } \\
1,75 \mathrm{~m} \text { (south) } \\
3,20 \mathrm{~m} \text { (north) }\end{array}$ & $\begin{array}{l}\text { Closed, under } \\
\text { the pedestrian } \\
\text { path and }\end{array}$ \\
\hline $\begin{array}{l}\text { Roadside land- } \\
\text { used activity }\end{array}$ & $\begin{array}{l}\text { Office } \\
\text { residential } \\
\text { and micro- } \\
\text { trading* }\end{array}$ \\
\hline $\begin{array}{l}\text { Road Capacity } \\
\text { (passenger car } \\
\text { equivalent/ hour) }\end{array}$ & $5.430 \mathrm{pcu} / \mathrm{hr}$ & $5198 \mathrm{pcu} / \mathrm{hr}$ \\
\hline
\end{tabular}

Note: *Side barriers on-road sections are categorized as moderate because there are several shops on the side of the road, and there is parking activity using the road body.

\subsection{Road Traffic Volume}

Traffic data collection is carried out on busy days (weekdays), for 12 hours (06.30-18.30WIB) continuously. Weather conditions at the time of the survey were a sunny day. Data interval recorded for traffic volume is based on vehicle classification; a time interval is 15 minutes. The recording of the number of vehicles passing is carried out in both directions of the vehicle flow (in units of $\mathrm{pcu} / \mathrm{hr}$ ).

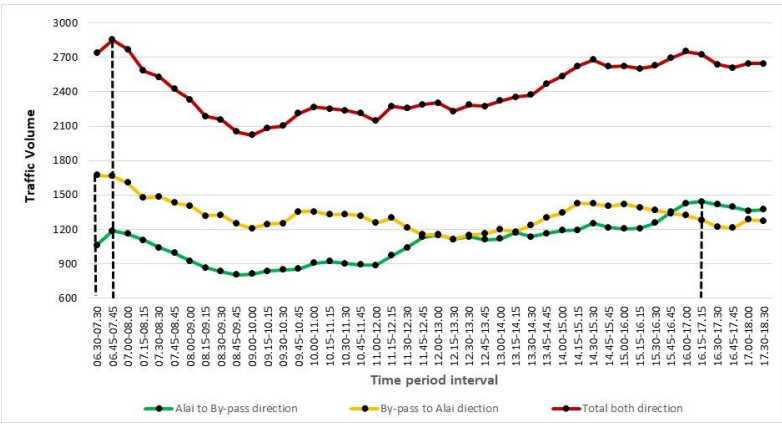

Fig. 5. Traffic volume of Alai - By-pass road (pcu/hr)

The survey obtained the peak traffic flow conditions of Alai - By-pass road:

- from Alai to By-pass (West to East direction), is at 16.15-17.15WIB, the traffic volume of 1442 (pcu/hour)

- from the By-pass to Alai (East to West direction), it is 06.30-07.30WIB, traffic volume of 1672 (pcu/hour)

- The total of both directions, is $06.45-07.45 \mathrm{WIB}$, with a traffic volume of 2853 (pcu/ hour)

The saturation degree (DS) value at the peak hour (06.45-07.45WIB) of the existing traffic conditions of the Alai - By-pass Road is 0.53, and the Service Level Index (ITP) value is $C$, that the traffic flow condition is stable, but the speed of the vehicle's motion is controlled by current conditions traffic.

Then, a simulation is conducted which scenarios Tsunami occurs, and several assumptions are made to obtain additional traffic volume due to the Tsunami disaster. Several factors, including: influence these assumptions

- Catchment areas of residents who are expected to pass the selected evacuation road when a tsunami occurs,

- A number of residents, family heads, and age distribution of residents who live in the catchment area. The number of residents who were still in the catchment area at the time of the tsunami were calculated from the data of the ratio of school-age children (to be in the school area, not at home) so that the prediction of the number of residents at home during the morning would be reduced from this ratio. Vice versa, for the elderly, they are assumed to be at home. 
- The ratio of ownership of light vehicles per family in the city of Padang is 0.16 , while for motorbikes is 1.13 [12].

- Activities of land use assumed for traffic volume in predictions are activities caused by markets, offices, schools, etc. (tourism, accidental passing, and so on).

- The types of vehicles used (based on interview surveys) are heavy vehicles, light vehicles, motorcycles, un-motorized vehicles, and 3-wheel motor vehicles, with the percentage composition of vehicle types as shown in Fig. 6.,

- The direction of traffic flow is assumed to be one direction, that is, towards the high area.

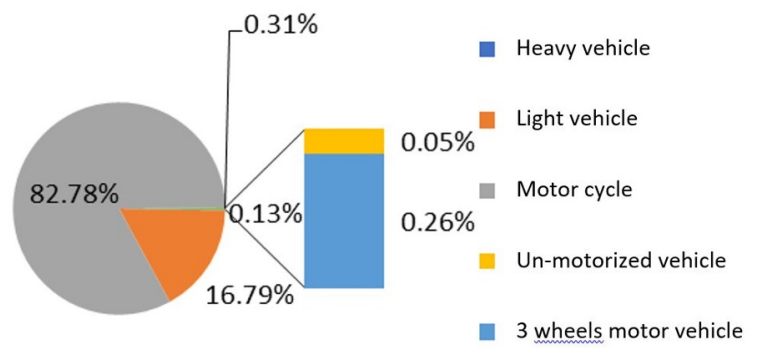

Fig. 6. Types and composition of vehicles

Based on the assumptions above, a total tsunami traffic volume can be obtained, which is the sum of (a) existing traffic volumes (normal conditions), (b) additional traffic volumes (predicted if a Tsunami occurs). The recapitulation of the traffic volume of the simulation results is presented in Fig. 7.

- The peak hour for additional traffic volumes is 16.0017.00WIB with a total volume of $3617 \mathrm{pcu} /$ hour,

- The peak hour for total Tsunami traffic volume is 16.00-17.00WIB, with a total volume of 6368 $\mathrm{pcu} /$ hour.

Thus, the Saturation Degree (DS) value at peak hours for the total Tsunami traffic volume of the Alai - By-pass Road, is 1.19 and the Service Level Index (ITP) is F, that the current conditions are forced, the speed is low, the volume is above capacity, and there is a long queue.

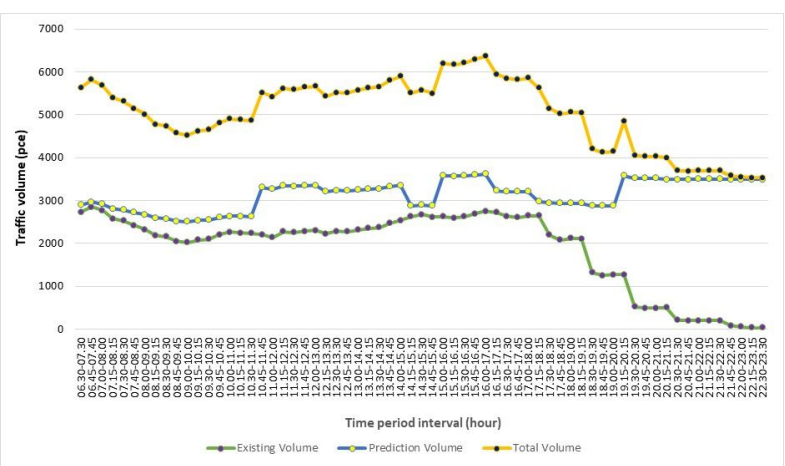

Fig. 7. Total Tsunami traffic volume of Alai - By-pass road (pcu/hr)

The same stage of analysis was also carried out for the Raden Saleh road, and the results obtained:

- the peak hour traffic volume in the existing condition is $1,377 \mathrm{pcu} / \mathrm{hr}$ at $17.00-18.00$ with the saturation degree
(DS) value is 0.25, and the Service Level Index is classified as good, where the vehicle runs smoothly.

- The total traffic volume in the Tsunami disaster scenario is $4,949 \mathrm{pcu} / \mathrm{hr}$, with a saturation degree (DS) value of 0.91 , with a Service Level Index the service conditions are poor, where the vehicle is running with many obstacles.

\section{Conclusion}

The results of observation and analysis of two Tsunami evacuation roads in Padang Municipality indicate that:

- Under normal traffic conditions, the performance of the Tsunami evacuation road section is at level $\mathrm{C}$ of the Service Level Index (ITP), meaning that traffic flow conditions can still be said to be stable and moderate traffic density.

- In the continuous evacuation route in Sector-IV, it turns out that there are differences in capacity between the sections of the road that have been designated as the tsunami evacuation road section. Efforts from the Padang municipal government are needed so that that tsunami evacuation sections can be matched or adjusted to capacity requirements.

- The performance of the Alai - By-pass (East) section would turn out to be bad if a Tsunami struck at 16.0017.00 WIB. In this period, the volume of traffic that will arise due to the evacuation of residents from the western part of the municipality of Padang will exceed the volume capacity of the road section. So the risk of congestion will be significant because the current condition is forced, low speed, there is a long queue. Traffic management is needed at peak hours for these roads. Increasing capacity without changing the dimensions of the road can be done, for example, parking bans or stopping at the shoulder/curb in some parts of the Alai - By-pass.

- The degree of saturation ratio and the ratio between the capacity of sections of Tsunami evacuation routes can be proposed as a parameter for assessing the performance of Tsunami evacuation roads in urban areas, through the simulation approach of the traffic volume of the road segments, based on the calculation of the population, vehicle ownership, use land and time for activities. For each of these parameters, more detailed statistical and correlation tests are needed.

The author thanks the Directorate of Research and Community Service (DRPM) of the Ministry of Research, Technology, and Higher Education (Kemenristekdikti RI) for providing research funding through the Master Thesis Research (PTM) scheme with contract number 051/SP2H/LT/DRPM/2019. A thank you also goes to the Research and Community Service Institute, Universitas Andalas, for helping with the administration of research and disbursing research funds, with contract number T/31/UN.16.17/PT.01.03/PKR-Kebencanaan/2019.

\section{References}

1. Government of the Republic of Indonesia, UndangUndang Republik Indonesia Nomor 24 Tahun 2007 tentang Penanggulangan Bencana. Jakarta. (2007) 
2. Padang Municipality Regional Development Planning Agency, Rencana Tata Ruang Wilayah Kota Padang Tahun 2010-2030. Padang Municipality (2012)

3. Indonesian National Standardization Agency, SNI 7766: 2012, Jalur Evakuasi Tsunami. Jakarta, Badan Standardisasi Nasional, Jakarta (2012)

4. Indonesian National Standardization Agency, SNI 7743:2011, Rambu Evakuasi Tsunami. Badan Standardisasi Nasional, Jakarta (2011)

5. R.S. Dewi, A-Gis Based Approach of an Evacuation Model for Tsunami Risk Reduction, J. Integr. Disaster Risk Manag., Vol.2 No.2 pp.108-139, ISSN: 2185-8322, DOI.10.5595/idrim.2012.0023 (2012)

6. Z. Alhadi., Kesiapan Jalur dan Lokasi Evakuasi Publik Menghadapi Resiko Bencana Gempa dan Tsunami di Kota Padang. Humanus, UNP, Padang. Vol.XIII No.1. pp.35-44. DOI: https://doi.org/ 10.24036/jh.v13i1.4095
7. S. Scheer, A. Gardi, R. Guillande, G. Eftichidis, V. Varela, B. de Vanssay, L. Colbeau-Justin. Handbook of Tsunami Evacuation Planning. JRC Scientific and Technical Reports: Italy (2011)

8. F. Ashar, Amaratunga, D., Sridarran, P., Haigh, R. Chapter 18 - Practices of Tsunami Evacuation Planning in Padang, Indonesia, Coast Manage., pp.399-433, Academic Press, https:/doi.org/ 10.1016/B978-0-12-810473-6.00019-4 (2019)

9. D. Jokowinarno, Mitigasi Bencana Tsunami di Wilayah Pesisir Lampung. Rek J Ilmiah FT, Unila, Vol.15 No.1 pp.13-20 (2011)

10. Sugeng Intoro, Mirza Irwansyah, Ismail AB2013, Kajian Jalur Evakuasi dan Titik Evakuasi Bencana Gempa Bumi Berpotensi Tsunami Berbasis Masyarakat, Rona Lingkungan Hidup J of Env., Vol.6 No.2 pp.43-51, (2013)

11. Director General of Highways, Manual Kapasitas Jalan Indonesia (MKJI). Jakarta (1997)

12. Padang Municipality Central Statistics Bureau, Padang Dalam Angka 2018, BPS Padang (2019) 